\title{
Trade influences in Australia's allocation market: can allocations provide environmental water?
}

\author{
A. Loch $^{1} \&$ H. Bjornlund ${ }^{1,2}$ \\ ${ }^{1}$ Centre for Regulation \& Market Analysis, School of Commerce, \\ University of South Australia, Australia \\ ${ }^{2}$ University of Lethbridge, Canada
}

\begin{abstract}
Over the last 25 years water markets in Australia have been used to transfer water entitlements and allocations between irrigators, helping them to manage the risks associated with water supply and the demand for structural change. More recently governments have entered entitlement markets to purchase water for the environment. This paper hypothesises that a focus on purchasing entitlements will not motivate a sufficient number of irrigators to engage in the provision of environmental water. It is hypothesised that governments may need to enter the allocation market to secure long-term arrangements for counter-cyclical provision of environmental water. Avoiding any negative impacts of interference on the traditional users of this market requires a greater understanding of how irrigators currently use allocations, and what drives their decisions to buy and sell. This paper provides the findings of qualitative research involving 39 irrigators in three states within the Murray-Darling Basin in Australia. The findings provide a preliminary assessment of the factors influencing irrigators' decisions to trade allocations and how these factors change across and within seasons. Irrigator attitudes toward government use of the allocation market to support counter-cyclic environmental water provision are also examined. Overall, irrigators appear comfortable with the notion of trading in allocations with the government, rather than in entitlements alone.
\end{abstract}

Keywords: allocation trading, environmental water provision, trade influences, Murray-Darling Basin. 


\section{Introduction}

Many of Australia's rivers have been recognised as being over-allocated, with little water remaining for the environment and eco-system health. One such river system is the Murray-Darling Basin (MDB) in Australia's south-east. To address this situation governments at the state and federal levels have introduced policies to return water to the environment [1]. Initially emphasis was placed on the use of regulatory planning processes. However these processes have largely failed due to a prolonged period of extreme drought. More recently governments have changed their strategy and are now trying to achieve environmental outcomes by purchasing water entitlements in the water market.

Entitlements represent an access right to water. Without that access irrigation is impossible. To irrigators entitlements therefore constitute the single biggest asset they own, as they provide a degree of income certainty. In recognition of this irrigators have been reluctant to sell their entitlements. There is, however, an alternative water market in which the seasonal right to use water is traded rather than outright transfer of ownership-the allocation market. This market has been far more readily accepted by irrigators [2].

The premise of this research is that irrigators will be reluctant to sell their entitlements to governments. This research also hypothesises that the allocation market is more appealing to irrigators for the provision of environmental water. Warnings of dire market consequences from government intervention into the entitlement market have already been sounded [3]. Similar concerns would no doubt surface should the allocation market also be targeted for recovery purposes. A better understanding of how irrigators use this market, what influences their decisions and how these factors vary within and between seasons will allow the government to plan their environmental purchases. Appropriate planning based on such knowledge will cause minimum disruption to traditional market operations and thereby minimize socioeconomic impacts.

Previous research into water markets has examined the drivers of allocation price and volume traded, particularly in the Goulburn district of Victoria [4-6]. However, specific comprehension of what drives allocation trade decisions across and within seasons requires further investigation [6]. The objective for this research is to extend the understanding of allocation trade behaviour using cross-sectional analysis of water trade influences among irrigators in the southern MDB. The principle methodological approach is qualitative with a view to inform later quantitative research and more generalisable results.

\section{Methods}

\subsection{Research design}

This research began with the assumption that irrigators would be reluctant or unwilling to part with their entitlements, suggesting that alternative trade products would be needed to recover sufficient environmental water to meet government objectives. Alternative methods have been suggested in previous 
papers [7-9] but the government's potential entrance into the allocation market has never been tested amongst irrigators to gauge their attitudes. The intent of this research is to provide emergent theory or to extend the theoretical understanding [10] of issues related to irrigator trade in the allocation market, including attitudes to possible government intervention.

Using the interpretivist paradigm [11] the research design centred upon collecting qualitative data from irrigators who are actively trading in water markets. To broaden existing water trade knowledge irrigators in the three southern MDB states (i.e. New South Wales (NSW), Victoria and South Australia (SA)) were targeted. The collection of data followed a naturalistic methodological approach [12] into a phenomenon through the subjective accounts of those that have experienced it [13]. The experiential questions for the research were determined a priori in an effort to keep subjective discussions on a broadly focused track. These questions included:

- what influences irrigator trade in water allocations across and within seasons;

- what drives irrigator trade in entitlements; and

- would allocation products (e.g. option contracts or leaseback agreements) increase the willingness to sell water to the environment.

\subsection{Sample}

A maximum variation approach was used to identify the sample [12] so that common patterns could be identified in irrigators' use of water markets. The sample was selectively chosen [11] to represent small family to large corporate operators, district irrigators and private diverters, different irrigation zones and commodity groups, and a mixture of young and old irrigators.

The use of maximum variation sampling provided sufficient breadth within the sample, a short data collection timeframe minimised data distortions introduced by changes over time, and a minimum of one and a half hours for each interview provided depth of data [14]. The use of maximum variation and selective sampling techniques facilitate the collection of common and divergent experience patterns during a particular period. In this case, the experiences occurred during a period of prolonged drought, severe water scarcity, and low commodity prices. Irrigators in SA were hit particularly hard. Prior to 2006 they had never expected or experienced lower than $100 \%$ allocations. Further, due to the dominance of permanent plantings SA irrigators are very vulnerable to low allocations. Since 2006 SA allocations have not reached $100 \%$, and irrigators there have experienced allocations as low as $18 \%$. These contextual influences must be taken into account when analysing the data [15]. All participants were male, aged in their early 50s (average age 53 years) and $>75 \%$ in each state were full-time irrigators earning a majority of their income from irrigated farming.

\subsection{Procedure}

Lists of potential participants were provided by irrigator organisations in SA and NSW, and by a commercial list provider in Victoria. Irrigators were contacted by 
telephone and assessed against the selected criteria. If suitable, the research project was described and where the irrigator indicated a willingness to participate an interview time was arranged. Eventually 39 candidates were chosen-14 in SA, 12 in NSW and 13 in Victoria. Prior to the interview each participant received a small questionnaire to be completed either prior to or during the interview. The mixture of qualitative and quantitative methods provides insight that each method alone might not achieve [16].

Following the tenets of interpretivist and naturalistic methodological design [12] a semi-structured interview was prepared, providing a schedule of questions to be explored with each irrigator. This approach avoided predetermined responses but ensured that basically the same information was obtained from each participant [15]. An interview guide was also prepared, leaving the interviewer free to explore or probe within and outside these predetermined areas of inquiry. During the interviews an approach of empathetic neutrality was sought to achieve a non-judgemental, balanced report $[14,15]$.

Interviews were conducted by the first author who had previous experience as an irrigation farmer. Hoepfl [15] suggests that shared background affords the interviewer with sensitivity to emergent theory and a capacity to gauge interesting lines of inquiry in the field. Shared experience also provides the interviewer the ability to process data as it becomes available, provide immediate feedback, seek further clarification, incorporate emergent issues from early into later interviews and explore atypical or unexpected responses [15]. The interviews averaged one-and-a-half hours, were audio recorded and transcribed. Interviews were typically conducted in the irrigator's home or place of business, although some were held in public places for convenience.

\subsection{Analysis}

This research is classified as grounded theory seeking [17]. The emphasis is upon further investigation as a consequence of the theory generated. In line with this approach, the constant comparative method was utilised to allow for the creation of generalised theoretical notions about the phenomenon under study, with the intent of further quantitative analysis of the theory at a later stage [18]. This process required the repeated comparison of text sections to identify patterns in farmer experiences. In this way theoretical foundations with explanatory power were eventually derived, as detailed below.

In line with the approach advocated by Aronson [19] the transcripts were firstly read to identify relevance to the issues of interest (e.g. within season allocation trade) as well as other emergent categories (e.g. the provision of ecosystem services). Similar concepts that described abstract representations of events or actions/interactions relevant to the research were open coded into categories. Each category collectively held examples of more than one related concept from the data. This process systematically summarised the data by relating criteria around a central issue [20]. Using NVivo software the categorised sections of text were next coded axially. This process identified underlying commonalities and attributes on which phenomena could be further categorised. The resulting analysis was then placed into a matrix that included 
main and sub-category listings, explanatory information about that grouping and possible research questions. It should be noted that the results are derived then from irrigator statements which may, or may not, reflect accurate facts.

Triangulation was also applied to the data as a means of generating trustworthiness in the analysis [14]. 'Methods Triangulation', as applied herein, is based on the degree of convergence present between the findings of this research and the work of prior quantitative studies. The closeness of convergence between findings on one hand, and the alternative theories offered by this research on the other hand lends credibility to the research and suggests further investigation. Finally, the emergent categories were compared to concepts or explanatory models presented in the existing literature.

\section{Results}

\subsection{Across season allocation trade influences}

Irrigators state that they tend to sell allocations on the basis of income generation, covering fixed access charges, surviving until sale and exit or having surplus water. A majority of irrigators who discussed the issue in the present scarce supply context reported that they were able to generate more income from water trade than farm production. That is, if water earned less from use in crop production than on the market, it would be sold seasonally for cash flow. Another group of irrigators reported that as long as the trade covered any fixed costs of water access they would be satisfied. These irrigators derived their income from farming, but recognised the burden of fixed charges in the current low allocation context and saw allocation trade as one way to meet such expenses. A small group of irrigators discussed allocation trade across seasons as a means of surviving until they could sell the farm and exit from the industry. These irrigators had sold parts of their entitlements to reduce debt or financial pressure, and were now awaiting an opportune time to sell remaining assets. Despite the drought a few irrigators reported having surplus water to trade as a consequence of efficiency gains. They now traded this water each year to supplement their income or to maintain a history of use.

Irrigators tended to buy allocations on the basis of necessity and the current unusual allocation conditions. Irrigators discussed purchasing across seasons to protect permanent crops or their existing investments in stock and equipment. Usually this investment had been based on historical access to reliably high allocation levels. Such activity was reported predominantly by irrigators in the horticulture industry. Very few dairy irrigators discussed buying out of necessity during the interviews, instead following a current strategy of stock reduction. Another group of irrigators discussed purchasing allocations because of the unusual situation at present, their limited experience with low allocations and the current uncertainty associated with high security licenses. Typically in the past, these irrigators had not used the allocation market as traditional entitlements were adequate. Now however, they were being forced to buy allocations to meet shortfalls in supply. In SA particularly, under the current drought, high security 
entitlements could not offer anywhere near the allocation level of similar high security entitlements in NSW, prompting the purchase of allocations in recent years by SA irrigators to supplement their dwindling allocations.

\subsection{Within season allocation trade influences}

\subsubsection{Early season trade influences (Sep-Nov)}

When discussing influences to sell allocations early in a season the reasons typically revolved around price, nature of the entitlement and market distortions. The issue of seeking to maximise profit from the early sale of allocations is not overtly discussed, but is clearly a driver for irrigators who can access their allocation early and trade while the market retains some volatility. Such volatility leads to higher early prices, which simplifies the decision for irrigators with annual crops. This is particularly the case in NSW where sizable allocations can be announced in the opening months of the season. Those with high security entitlements therefore have the opportunity to engage in profitable early trade. Finally, the prospect of market distorting activity such as trade embargos to limit the loss of too much water from any one area or the prospect of rule changes associated with trading can also drive irrigators to sell early in the season and avoid being excluded later. For example, an embargo on allocation trade occurred in the Murrumbidgee Irrigation District (MID) in 2009 and as such is a purely contextual driver of trade. Changes to early season carryover rules in the MID were also an example of uncertainty or market frustration for irrigators.

The decision to buy allocations early in a season is reportedly based upon issues of cash flow, risk management or market interference. If water is required to start or support an existing crop, and therefore needs to be purchased, one group of irrigators reported issues of finance as influencing their decision. Some need to access debt funding to support the crop immediately while others use recent commodity payments as a source of finance. If neither is available they cannot trade; or are forced to trade during the season as and when cash flow becomes available. Another group of irrigators discussed their desire to avoid the impacts of continued low allocation volumes during the season by purchasing water early as a risk management strategy. They seemed willing to pay higher prices to achieve this outcome-in a sense like paying insurance to avoid riskespecially if they had not managed to buy carryover water in the previous season or if carryover announcements varied between trading periods. Lastly, during the 2008 and 2009 seasons in SA the government announced offers of critical allocation water to assist horticultural growers to protect their valuable crops. The prospect of such water lessens the need to 'rush into' the market and allows some irrigators the option of waiting and seeing what the season, and state government does before committing to a decision. This is a good example of allocation market interference.

\subsubsection{Middle season trade influences (Dec-Feb)}

While irrigators who had not sold allocations early in the season due to risk aversion or indecision discussed accepting whatever sale price they could in the middle months, the majority of the issues in middle allocation trade appear to 
revolve around buying rather than selling. These issues include price stabilisation, allocation or market predictions, seasonal variation and market distortions. Irrigators in this group reported that once the early trade volatility and seasonal allocation uncertainty begin to settle, market prices stabilise. Those irrigators who are more accepting of risk might choose to buy now with the expectation of a lower price. Many irrigators discussed having learnt from panic buying in 2007, when allocations were expected to stay around $16 \%$ for the year and prices quickly escalated to $\$ 1,200 / \mathrm{ML}$. Such panic buying is unlikely to be seen again and irrigators across the states indicated that they had set upper purchasing bounds of around \$300-350/ML.

These same irrigators therefore study the market and seasonal allocations, using various sources of information. They attempt to enter the market at the 'best' time and price points. However, other factors such as seasonal variability and hot/dry periods during the spring and summer months may force higher than expected water use, in turn prompting middle season trade to secure additional water. Finally, as occurred in 2009, market distorting factors such as the federal government's refusal to execute entitlement purchase contracts previously promised to irrigators saw some Victorian irrigators enter the market unexpectedly during Oct/Nov of that season. These irrigators needed water to either irrigate new 'late' crops or improve the quality of existing crops since they once more represented the major farm income source.

\subsubsection{Late season trade influences (Mar-May)}

Irrigators who buy allocations late in the season typically discuss balancing their water account, risk attitude, carryover demand and seasonal variability as issues. For example, if irrigators have exceeded their usage during the year they will need to buy water to balance the account with their water provider to avoid hefty fines for excess use. This could occur in the middle of the season, but most irrigators prefer to do this at the end of the season, possibly because prices traditionally have been lower at that time. Alternatively the risk profile of the irrigator also influences their decision to buy late. If the irrigator is a risk taker, they discuss gambling on later water price reductions, preferring to see the season through and buying water for crop-finishing purposes. If the irrigator is more risk adverse, they report entering the market later to buy carryover water in preparation for anticipated low allocation announcements next year. In addition, a small group of irrigators had experienced longer than typical hot or dry periods in recent years, prompting their forced entry into the market later in the season to secure additional water.

When selling late in the season irrigators predominantly reported their influences for doing so as expecting higher prices from late carryover demand, having surplus water to sell and avoiding the loss of unused water. As mentioned above, if future water is expected to be scarce carryover demand will be high. Some irrigators with surplus water count on that for late season price 'kicks' and sell it at this time. A smaller number of irrigators also discussed losing unused water due to carryover restrictions and 'parking' that water on another irrigator's account with surplus carryover capacity. Once the new water year started, the 
restricted irrigator could access that water for opening supply. In these cases irrigators tried to beat what were seen as frustrating system rules.

\subsection{Entitlement trade influences}

Discussion on the topic of entitlement trade provided emergent sub-categories related to buying, selling and outright refusal to trade. When discussing buying entitlements a group of irrigators suggested that the uneconomic nature of farming and high prices of entitlements precluded purchase at present. Current poor returns from almost all traditional commodities mean irrigators cannot justify going into debt to finance the purchase of entitlements. Government demand for entitlements is also providing a price floor of around $\$ 2,000 / \mathrm{ML}$ for high security and $\$ 1,000 / \mathrm{ML}$ for general security entitlements, which irrigators can't justify or match in the current context.

On the topic of selling entitlements, the discussion centred upon forced rather than willing sale, capitalisation to continue farming, retirement/resentment, future uncertainty or selling for the 'right' price. When discussing the government program to buy water for the environment most irrigators stated that there were very few willing sellers, and that irrigators taking part had been forced to sell due to debt or other financial pressures. Another group of irrigators indicated that, while not pleased about selling, they had been willing to do so, capitalising their assets to cover debt or the cost of restructuring, while also continuing to irrigate with allocation purchases. Some irrigators reported feeling resentment toward or uncertainty about the future of irrigation. Such feelings or the prospect of eminent retirement with no family successor had influenced their decision to sell. Lastly, a few irrigators said that they were happy to sell their entitlements because they perceived market value would drop in future and now was the opportune time to sell. Others stated that they 'would' be happy to sell if offered the right price - typically well above current market offers. Additionally, there were some irrigators who, when asked about entitlement trade, simply commented that they would refuse to sell for any reason. These irrigators mentioned that they simply couldn't or wouldn't sell their entitlements, or that community impact concerns prevented the sale. Irrigators in this group stated that they need the entitlement and were using it for farming. They described the water as an asset and major part of their farm value and would only sell if that value was recognised; again typically well above market prices. A very small group of irrigators, predominantly in Victoria, discussed community impacts as the reason for not selling their entitlement.

\subsection{Option/leaseback attitudes}

A range of positive and negative attitudes emerged from discussion about the use of options or leaseback products to secure environmental water. The positive focused on broader trade products, leaseback appeal, counter-cyclical funding opportunities and surplus water trade. Almost every irrigator who discussed this topic expressed comfort about using allocation products to provide environmental water, and had no difficulty entering into agreements with the 
government. Discussion by some irrigators showed that they perceive the current entitlement purchasing policy as lacking in vision or short-sighted, and that an expanded list of trade products is warranted. The concept appealed more to annual croppers, especially upon the return to normal seasonal supply conditions. One group of irrigators picked up on the capacity of such programs to be selffunding through counter-cyclical trade arrangements (i.e. buying when allocations are high and prices low; selling when allocations are low and prices high), particularly if surplus water again becomes available and where fixed irrigator costs of access need to be met.

The negative discussion associated with this category included concerns about previous bad lease experiences, efficient water delivery and pricing. A few irrigators alluded to previously having bad experiences in long term leases with other farmers, especially in scarce supply years. Farmers need the water each year regardless, whereas governments might not. Another small group held concerns about how such water would be delivered through the system and that current environmental managers would be a barrier to such agreements. Finally, the issue of how such leases would be priced concerned a few irrigators, but if the price was acceptable the concept seemed worthy of further consideration.

\section{Discussion}

The results of this research offer valuable insight into the questions posed. In regard to the question of what influences allocation trade across and within seasons the prepared list of possible issues based on the literature proved useful, with expected issues appearing regularly through the discussions. However, other trade drivers also emerged. For example, previous research into irrigator activity in water markets mainly focused on price and volume traded, particularly in Victoria's Goulburn area. They did not examine three states at once but there are some interesting parallels and divergences. Bjornlund [21] discusses irrigators using the allocation market at different times to supplement or fully generate farm income, selling in some years and buying in others. As shown here these influences remain important factors in trade decision making, especially in the context of low allocations and during early season periods. Similarly Wheeler et al. [6] find that rainfall, evaporation and market conditions influence general allocation trade across seasons, but that to determine the real drivers of individual buying and selling would require more specific data. This study attempts to provide such data. Wheeler et al also found that as markets mature outlandish bids decrease as a function of irrigator experience, which is consistent with our findings on future panic trade. Seasonal effects on allocation trade, especially as a driver for late season activity based on lower prices have been reported in other studies [4], but drivers such as carryover based trade are new to the literature, having only been possible in the past few years.

The need to protect investment in permanent crops and capital equipment has also been found in previous research [5], particularly in the horticulture and dairy industries. A difference in this study is that dairy farmers no longer seem willing to pay premiums, and it is uncertain how long grape growers will continue 
purchasing with current poor commodity prices. Risk management strategies within and between seasons [22] and uncertainty have been linked to buying behaviour previously [23]. In this study the influence of risk attitudes seem particularly important for early or late within season decisions. It is not surprising that the current period of extended drought has caused farmers to place increased importance on risk management.

That irrigators utilise different allocation trade strategies across and within seasons in response to commodity prices, water prices, seasonal allocations, weather patterns and risk management strategies [21] is also supported by this research. However, other factors such as market distortions, fixed charges, surviving to exit, avoiding carryover losses and financial capacity to trade should perhaps also be taken into account. Further, the issue of end of season account balancing has previously been suggested as a late season allocation trade influence [6] and thus represents another variable of interest in the continuing research. Finally, another study by Wheeler et al. [24] found that the highest trade volume took place in January to March each year (middle seasonal trade). That is consistent with our findings of price and market stability during middle season, along with greater allocation certainty. Interestingly, Wheeler et al. suggested that the government can influence market activity by their involvement; this research has identified some specific examples of that interference.

The second question regarding influences of entitlement trade also shares some similar and divergent findings. For instance, that price is not yet a factor in entitlement demand [23] is a finding we would dispute in the present context. Utilisation of entitlement trade to, among other things, become debt free and stay in the community [25] is discussed in this study, but contrary to previous research there is little mention of lifestyle or off-farm income as drivers in the adjustment process. Equally, while the issue of community barriers to entitlement sales has featured in earlier studies [26, 27], particularly in public opinion or debate, it does not seem to share as much priority here in private reflections on the issue. Finally, some of the uses of entitlement sales identified in this paper-i) to delay exit for as long as possible; ii) finance irrigator retirement; or iii) await a better time for capital-transfer-have all been mentioned in the literature, and are all associated with a desire to keep farming or remain in local communities [27]. The important finding here is that much of the selling seems to be taking place during scarce water supply conditions in a forced rather than willing way due to debt, other financial or looming retirement reasons. The purchase of entitlements by anyone other than government buyers seems unjustifiable.

In relation to the third question the concept of diverse trade products such as derivatives or options have been portrayed elsewhere [4, 27, 28] as more efficient products that might appeal to irrigators and governments as a means of resolving supply issues in advance. This study supports the finding that alternative allocation products (e.g. supply option contracts and long-term lease arrangements) would appeal to irrigators. At present though, these findings are not generalisable to the larger population because the sample here is very small. 
We intend to address this with a later quantitative survey. Also, the context is one of drought and scarce water supply; if the seasons returned to normal the attitudes and experiences reported here would no doubt be different.

\section{Conclusion}

Support for the hypothesis that irrigators would be reluctant to engage in providing environmental water via the sale of entitlements is mixed. While irrigators appear unwilling to sell, in many cases they are being forced to do so because of drought and financial pressure. Further, because the interviews only targeted irrigators currently active in trading-i.e. not those who have already exited or have never participated in any kind of water trading-it is difficult to state conclusive findings. There is, however, evidence to suggest that alternative allocation trade products could appeal to irrigators in the process of water recovery should the entitlement market falter for any reason. The research provides a valuable start to expand the theoretical understanding, but the findings need to be further tested to determine wider acceptance and policy value.

\section{Acknowledgements}

This research is part of a larger project funded by the Australian Research Council and supported by six industry partners: Murray-Darling Basin Authority, CSIRO Water for a Healthy Country Flagship Program, Department of Sustainability and Environment in Victoria, Goulburn-Murray Water, the New South Wales Office of Water and the University of Lethbridge in Canada.

\section{References}

[1] Crase, L., O'Keefe, S. \& Dollery, B., Water buy-back in Australia: Political, technical and allocative challenges, 53rd Annual Australian Agricultural and Resource Economics Society Conference, Cairns, Australia 2009.

[2] Ashton, D. \& Oliver, M., An economic survey of irrigation farmers in the Murray-Darling Basin: Industry overview and region profiles, ABARE, 2008.

[3] Dixon, P., Rimmer, M. \& Wittwer, G., Modelling the Australian government's buyback scheme with a dynamic multi-regional CGE model, Centre for Policy Studies, Monash University Melbourne, 2009.

[4] Bjornlund, H., Efficient water market mechanisms to cope with water scarcity, International Journal of Water Resource Development, 19, pp. 553-67, 2003.

[5] Bjornlund, H. \& Rossini, P., Fundamentals determining prices in the water market for water entitlements - An Australian case study, International Journal of Water Resources Development, 23(3), pp. 537-53, 2007.

[6] Wheeler, S., Bjornlund H., Shanahan M. \& Zuo A., Price elasticity of water allocation demand in the Goulburn-Murray irrigation district, Australian Journal of Agricultural and Resource Economics, 52(1), pp. 37-55, 2008. 
[7] Scoccimarro, M. \& Collins, D., Natural resource buybacks and their use to secure environmental flows, Land \& Water Australia, Canberra, 2006.

[8] Thoyer, S., How to reallocate water rights when environmental goals conflict with existing entitlements, International Journal of Sustainable Development, 9(2), pp. 122-37, 2006.

[9] Breckwoldt, R., Review of the 2007-08 water entitlement purchases: Final Report, Hyder Consulting, Melbourne, 2008.

[10] Bazeley, P., Qualitative data analysis with NVivo, 2nd ed., Sage Publications: London, 2007.

[11] Gladstone, J., Dupuis, S. \& Wexler, E., Changes in family involvement following a relative's move to a long-term care facility, Canadian Journal on Aging, 25(1), pp. 93-106, 2006.

[12] Lincoln, Y.S. \& Guba, E.G., Naturalistic inquiry, Sage Publications Inc.: Beverly Hills CA, 1985.

[13] Giorgi, A. \& Giorgi, B., Phenomenology (Chapter 3). Qualitative Psychology, ed. J.A. Smith, Sage Publications: London, pp. 25-50, 2003.

[14] Patton, M.Q., Qualitative evaluation and research methods. 3rd ed., Sage Publications: Thousand Oaks CA, 2002.

[15] Hoepfl, M., Choosing qualitative research: A primer for technology education researchers, Journal of Technology Education, 9(1), pp.47-63, 1997.

[16] Russek, B.E. \& Weinberg, S.L. Mixed methods in a study of implementation of technology-based materials in an elementary classroom, Evaluation \& Program Planning, 16(2), pp. 131-42, 1993.

[17] Corbin, J. \& Strauss, A., Grounded theory research: procedures, canons and evaluative criteria, Qualitative Sociology, 13(1), pp. 3-21, 1990.

[18] Glaser, B., The constant comparative method of qualitative analysis, Social Problems, 12(4), pp. 436-45, 1965.

[19] Aronson, J., A Pragmatic View of Thematic Analysis, The Qualitative Report, 2(1), pg. 4, 1994.

[20] Strauss, A. \& Corbin, J., Basics of qualitative research, Sage Publications: Thousand Oaks CA, 1998.

[21] Bjornlund, H., Can water markets assist irrigators managing increased supply risk?: Some Australian experiences, Water International, 31(2), pp. 221-32, 2006.

[22] Bjornlund, H., Formal and informal water markets: Drivers of sustainable rural communities? Water Resources Research, 40 (W09S07), 2004.

[23] Wheeler, S., Bjornlund, H., Shanahan, M. \& Zou, A., Modelling demand for water entitlements in the Goulburn-Murray irrigation district of Australia. Water Down Under Conference, Adelaide 2008.

[24] Wheeler, S., Bjornlund, H., Shanahan, M. \& Zuo, A, Factors influencing water allocation and entitlement prices in the Goulburn area of Australia (Chapter 7). Sustainable Irrigation: Management technologies, Technologies \& Policies II, eds. Y. Villacampa-Esteve, C.A. Brebbia \& D. Prats Rico, WIT Press: Southampton, pp. 63-72, 2008. 
[25] Bjornlund, H., The socio-economic structure of irrigation communities: water markets and the structural adjustment process, Rural Society, 12(2), pp. 123-47, 2002.

[26] Edwards, J., Cheers, B. \& Bjornlund, H., Social, economic and community impacts of water markets in Australia's Murray-Darling Basin region, International Journal of Interdisciplinary Social Sciences, in press.

[27] Bjornlund, H., Markets for water allocations: Outcomes and impacts. Water Down Under Conference, Adelaide, 2008.

[28] Bjornlund, H., What is driving activities in water markets? Water, 30, pp. 30-6, 2003. 